\title{
DETERMINED ECOLOGICAL HUMAN HEALTH RISK FACTORS IN SINGLE FACTORY TOWNS ${ }^{1}$
}

\author{
V. Boev ${ }^{1}$, M. Boev ${ }^{1}$, L.Tulina ${ }^{2}$, A. Neplokhov ${ }^{2}$ \\ ${ }^{1}$ State Budgetary Educational Institution of Higher Professional Education "Orenburg \\ State Academy of Medicine" \\ ${ }^{2}$ Federal Budgetary Health Care Institution "The Orenburg Region Center for Hygiene \\ and Epidemiology" \\ Russia, 460000, Orenburg, 6 Sovietskaya st., Russia, 460000, Orenburg, 48 Kirova st.
}

\begin{abstract}
We have undertaken a comprehensive comparative assessment of quantitative relationships between the contribution of environmental anthropogenic factors and the indicators of individual and population carcinogenic and non-carcinogenic risks. This assessment confirms the influence of the major anthropogenic factors on children's health in single factory towns.
\end{abstract}

Key words: single factory town, individual and population carcinogenic risk, anthropogenic factors, children.

Negative trends in public health in Russia today develop from exposure to a number of environmental factors associated with the change in socioeconomic and medico-environmental living conditions $[5,6,7]$. Such changes are especially typical of small towns with one core industrial enterprise [3]. Almost $40 \%$ of the total number of cities in Russia is comprised of small towns including, according to the Town Planning Code (2004), towns with the population of 20-50 thousand people which means that every fifth Russian citizen lives here. In Orenburg Region, $42.6 \%$ of the population lives in rural areas (27\% of Russians live in rural areas); $58 \%$ of urban areas are comprised of small towns.

Taking into account a wide range of public health and environmental assessment criteria, we included in the research procedure an integrated differentiated analysis of the environmental quality based on the identification of xenobiotics in the air, water and soil on the basis of own field observations and socioeconomic monitoring databases including an assessment of noncancer and carcinogenic health risks in children $[4,8]$.

A negative impact of xenobiotics is reflected in all the natural environments since the main body of this agent falls on the ground being washed from the air in the form of precipitation accumulated in the accumulative environments. In order to decipher the region's 'chain or reasons' that determines the pathology of a specific population and find the chains that are easy to affect and thus remove unfavorable impact of risk factors, it is necessary to determine an objective connection between the level of environmental factors impact and the state of public health. At the same time, it is necessary to analyze the current negative trends in the environment from the position of integrated analysis of human-induced environmental factors using system analysis based on long-term socio-hygienic monitoring data.

The biggest air pollutants in the areas under study are: Gai Mining and Processing Works, Gai Non-Ferrous Metals Plant "Splav"; in Kuvandyk: South Urals Cryolite Plant, "Dolina" Machine Building Enterprise; in Mednogorsk: Mednogorsk Copper and Sulfur Plant; in Novotroitsk: Ural Steel, Novotroitsk Cement Plant, Novotroitsk Silicate Wall Material Plant, Novotroitsk Chrome Compounds Plant. We determined statistically significant differences in the levels of air pollution among the towns (Table 1). We identified the chemical elements with the

\footnotetext{
${ }^{1}$ Translated by Ksenya Zemnlyanova
} 
concentrations that exceed the permissible level: suspended substances in Novotroitsk - by 2.2 times, in Gai - by 1.7 times; nitrogen dioxide in Mednogorsk and Kuvandyk - by 1.8 times, in Novotroitsk - by 1.3 times; sulfate dioxide in Mednogorsk - by 2.9 times. The total air pollution indicator in Novotroitsk was 1.28 times higher than in Mednogorsk, in Kuvandyk it was 1.74 times higher, and in Gai - 2.7 times higher. Additive effects in the summation groups exceeded the permissible level in most cities, including:

- sulfur dioxide + nitrogen dioxide in Mednogorsk - by 4.6 times, in Kuvandyk - by 2.6 times, in Novotroitsk - by 2.3 times, and in Gai - by 1.2 times.

- sulfur dioxide + hydrogen sulfide in Mednogorsk - by 3.2 times, in Novotroitsk - by 1.2 times.

Table 1

The level of air pollution in industrial cities in 2005-2010

(in fractions of maximum permissible concentration)

\begin{tabular}{|l|c|c|c|c|}
\hline Indicator & Novotroitsk & Mednogorsk & Kuvandyk & Gai \\
\hline Sulfur dioxide & $0,82 \pm 0,30$ & $2,53 \pm 0,35^{*}$ & $0,63 \pm 0,17$ & $0,13 \pm 0,02^{*}$ \\
\hline Nitrogen dioxide & $1,37 \pm 0,06$ & $1,68 \pm 0,07^{*}$ & $1,76 \pm 0,10^{*}$ & $1,06 \pm 0,01$ \\
\hline Suspended substances & $1,99 \pm 0,21$ & $1,05 \pm 0,07^{*}$ & $1,15 \pm 0,06$ & $1,72 \pm 0,15$ \\
\hline Carbon monoxide & $0,51 \pm 0,07$ & $0,41 \pm 0,03$ & $0,47 \pm 0,04$ & $0,40 \pm 0,09$ \\
\hline Hydrogen sulfide & $0,27 \pm 0,03$ & $0,31 \pm 0,03^{*}$ & $0,27 \pm 0,03$ & $0,20 \pm 0,03$ \\
\hline To sum & $\mathbf{4 , 9 4}$ & $\mathbf{3 , 8 6}$ & $\mathbf{2 , 8 4}$ & $\mathbf{1 , 8 3}$ \\
\hline Sulfur dioxide + Nitrogen dioxide & $2,18 \pm 0,30$ & $4,2 \pm 0,38^{*}$ & $2,39 \pm 0,13$ & $1,19 \pm 0,09$ \\
\hline Sulfur dioxide + Hydrogen sulfide & $1,08 \pm 0,31$ & $2,84 \pm 0,37^{*}$ & $0,9 \pm 0,17$ & $0,33 \pm 0,02$ \\
\hline
\end{tabular}

Note: $*$ - confidence level as compared to the mean regional value $(\mathrm{p}<0,05)$.

When comparing the level of pollution in individual cities with an average regional level, it was determined that in Novotroitsk, the concentration of sulfur dioxide is 2.5 higher ( $p<$ $0,001)$; the concentration of nitrogen dioxide is 1.3 times higher in Kuvandyk $(p<0,01)$, and in Mednogorsk it is 1.2 times higher $(p<0,001)$. Despite the fact that sulfur dioxide in the cities of the region did not exceed the permissible level, its concentration in the air of Mednogorsk exceeded the average regional level by 1.2 times $(p<0,01)$. The total air pollution indicator (to sum) in residential areas was 3.4 for single-plant cities.

In accordance with the research objectives, we conducted an analysis of the concentration of ferrum, nitrates, ammonia, sulfates, chlorides, fluoride, boron, manganese, arsenic, lead, chrome, copper, molybdenum, selenium, zinc, aluminum, the level of hardness and mineralization, and calculated the total indicator Kwat in drinking water in the residential areas of the regions' small towns with single nonferrous and ferrous metallurgy (Novotroitsk, Mednogorsk, Kuvandyk, and Gai). The results of a socio-hygienic monitoring for 2005-2010 showed that the single-plant towns under study have a high concentration of ferrum, chrome, manganese, arsenic, boron, and lead as well as a higher concentration of aluminum and selenium (Table 2).

Consequently, the qualitative characteristic of drinking water in small towns did not exceed the hygienic standards. At the same time, the total indicator analysis (Kwat) revealed a 
higher concentration of chemical components in the drinking water of Novotroitsk, and the drinking water of Gai had the lowest indicator (Table 3).

Table 2

Characteristics of sanitary and hygienic parameters of the drinking water in urbanized areas of single-plant towns in 2005-2010 $(\mathrm{M} \pm \mathrm{m})$

\begin{tabular}{|l|c|}
\hline \multicolumn{1}{|c|}{ Parameter } & Concentration, $\mathrm{mg} / \mathrm{l}$ \\
\hline Copper & $0,04 \pm 0,007$ \\
\hline Ferrum & $0,22 \pm 0,07^{*}$ \\
\hline Chrome & $0,007 \pm 0,001$ \\
\hline Zinc & $0,039 \pm 0,008^{*}$ \\
\hline Manganese & $0,06 \pm 0,008^{*}$ \\
\hline Boron & $0,13 \pm 0,014^{*}$ \\
\hline Fluoride & $0,19 \pm 0,02^{*}$ \\
\hline Lead & $0,005 \pm 0,001$ \\
\hline Selenium & $0,00026 \pm 0,00008$ \\
\hline Aluminum & $0,02 \pm 0,001$ \\
\hline Arsenic & $0,004 \pm 0,0006^{*}$ \\
\hline Molybdenum & $0,0039 \pm 0,0007^{*}$ \\
\hline Ammonium & $0,10 \pm 0,02^{*}$ \\
\hline Sulfates & $151,4 \pm 11,3$ \\
\hline Nitrates & $12,4 \pm 1,1$ \\
\hline Chlorides & $145,5 \pm 8,2$ \\
\hline Mineralization & $661,5 \pm 25,8$ \\
\hline Hardness, mg*eq/l & $6,4 \pm 0,35$ \\
\hline Total indicator (Kwater) & $\mathbf{5 , 7}$ \\
\hline
\end{tabular}

Note: $* \mathrm{P}<0,05$

Total indicator of the drinking water quality (Kwater)

\begin{tabular}{|l|c|}
\hline \multicolumn{1}{|c|}{ Town } & K water \\
\hline Gai & 3,7 \\
\hline Novotroitsk & 4,7 \\
\hline Mednogorsk & 4,4 \\
\hline Kuvandyk & 4,2 \\
\hline
\end{tabular}

Assessment of the human-induced impact in the towns under discussion for the period of 2005-2010 showed that in terms of human-induced impact on the air and hydrospace, the maximal impact was registered in Novotroitsk followed by Mednogorsk, Gail, and Kuvandyk.

Soil as an inherent part of the environment is the most important factor in the integrated human-induced impact on the condition of public health. It was determined that the metal pollution of soil is of local character and increases with proximity to stationary pollution sources $[1,2]$. For the purposes of the research, the quantitative characteristic of the soil pollution of the residential areas of single-plant towns was conducted on the basis of determination of the average concentrations of the chemicals in the soil and also by the total indicator (Ksoil) calculated in terms of gross and mobile forms of metal. Gross forms of elements in chemical compounds and the organic parts of the soil are non-mobile. Mobile forms of elements are known as the most reliable sources of information about environmental pollution.

For the purposes of the research, we conducted a comparative analysis of the concentrations of the elements under study in the soil of the residential areas of the region's 
single-plant towns with the enterprises specialized in nonferrous and black metallurgy (Novotroitsk, Mednogorsk, Kuvandyk, and Gai). Our analysis of the pollution level in singleplant towns showed that mobile nickel forms have the highest concentrations (1.4 times higher) (Table 4), but at the same time, other elements under study did not exceed the maximal permissible concentration (MPC) (approximate permissible concentration APC).

Specifically, the highest total indicator was registered in Mednogorsk which exceeded the average regional indicator (K soil-4,9) by at least 2 times (Table 5).

Table 4

Comparative characteristics of in the soil of residential areas of single-plant towns

\begin{tabular}{|c|l|c|c|}
\hline \multicolumn{2}{|c|}{ Metals } & $\begin{array}{c}\text { Concentration } \\
(\mathrm{M} \pm \mathrm{m}), \mathrm{mg} / \mathrm{kg}\end{array}$ & Compared to MPC (APC) \\
\hline \multirow{4}{*}{$\Xi$} & Nickel & $5,6 \pm 1,9$ & 1,4 \\
\cline { 2 - 4 } & Copper & $2,2 \pm 1,03$ & 0,7 \\
\cline { 2 - 4 } & Zinc & $10,64 \pm 1,18$ & 0,5 \\
\cline { 2 - 4 } & Lead & $1,5 \pm 0,2$ & 0,2 \\
\cline { 2 - 4 } & Manganese & $47,62 \pm 6,2$ & 0,3 \\
\cline { 2 - 4 } & Cobalt & $1,6 \pm 0,2$ & 0,3 \\
\cline { 2 - 4 } & Chrome & $0,9 \pm 0,09$ & 0,1 \\
\cline { 2 - 4 } & & K mobile soil forms & 3,64 \\
\hline
\end{tabular}

Table 5

Total indicator of soil pollution in the residential areas of single-plant towns (Ksoil)

\begin{tabular}{|l|c|}
\hline \multicolumn{1}{|c|}{ Town } & Total indicator of soil pollution (K soil) \\
\hline Mednogorsk & 11,8 \\
\hline Kuvandyk & 5,7 \\
\hline Novotroitsk & 4,5 \\
\hline Gai & 3,0 \\
\hline Region & $\mathbf{4 , 9}$ \\
\hline
\end{tabular}

The above analysis of the level of pollution of the residential areas in single-plant towns revealed the total impact including the constellation of air, soil, and water pollution and combined ways of entry into a human body. Table 6 shows that the absolute value of total human-induced impact in small towns includes air pollution $(24.5 \%)$, drinking water pollution (30.5\%), and soil pollution (55\%).

Table 6

Total environmental pollution indicator in single-plant towns

\begin{tabular}{|l|c|c|c|c|}
\hline \multicolumn{1}{|c|}{ Town } & Air & Water & Mobile soil form & K Integrated index \\
\hline Gai & 1,83 & 3,7 & 3,0 & 8,5 \\
\hline Novotroitsk & 4,94 & 4,7 & 4,5 & 14,1 \\
\hline Mednogorsk & 3,86 & 4,4 & 11,8 & 20,1 \\
\hline Kuvandyk & 2,84 & 4,2 & 5,7 & 12,7 \\
\hline K town & $\mathbf{3 , 4}$ & $\mathbf{4 , 2 5}$ & $\mathbf{6 , 2 5}$ & $\mathbf{1 3 , 9}$ \\
\hline
\end{tabular}

At the same time, taking into account a different number of factor-oriented assessments for different environments, we decided to calculate a graded indicator - hygienic grade that included the number of factors in the total pollution indicator of an environment under evaluation. With permissible level of impact, the indicator value must be $\leq 1$. 
Analysis of the urban areas showed that the highest hygienic grades in terms of chemical element concentration were determined for all environmental factors. The integrated index in all the environments exceeded permissible level. Assessment of a multi-component risk to children's health was conducted in terms of average indicators of the single-plant towns under study. We determined that in single-plant towns, copper $(\mathrm{HQ}=6,6)$, sulfuric acid $(\mathrm{HQ}=3,4)$, nitrogen dioxide $(\mathrm{HQ}=1,54)$, sulfur dioxide $(\mathrm{HQ}=1,49)$, and the sum of suspended substances $(\mathrm{HQ}=2,9)$ were the biggest contributors to the development of non-carcinogenic effects, with the account for the assessed hazard index (index - HA) and total indices (HI).

Table 7

Total hazard indices for the critical body organs and systems

\begin{tabular}{|l|c|c|}
\hline \multirow{2}{*}{ Total non-carcinogenic hazard index $(\mathrm{HI})$} & \multicolumn{2}{|c|}{ Single-plant towns } \\
\cline { 2 - 3 } & Air & Water \\
\hline Respiratory organs & 14,54 & - \\
\hline Blood & 0,20 & 0,02 \\
\hline Central nervous system & 0,39 & 0,01 \\
\hline Immune system & 0,20 & 0,003 \\
\hline Cardiovascular system & 0,51 & 0,02 \\
\hline Reproductive system & - & - \\
\hline Kidney & 0,42 & 0,001 \\
\hline Hormone system & - & - \\
\hline Systemic lesion & 6,6 & 0,054 \\
\hline Total HI & 22,86 & \\
\hline
\end{tabular}

When assessing the risk of non-carcinogenic effects on certain organs and systems that are frequent targets for pollutants, we calculated the total hazard indices (Table 7). We determined that in single-plant towns, the total non-carcinogenic risk to children's health from air pollutants by far exceeds that from drinking water pollutants. When assessing the risk of noncarcinogenic effects on certain organs, we determined that the biggest risk associated with a chemical impact on respiratory organs in small towns was presented by sulfuric acid (very high risk), hydrogen sulfide, sulfur dioxide, nitrogen dioxide, and suspended substances (average risk).

Table 8

Total individual (ICR) and population (PCR) carcinogenic risk to children's health

\begin{tabular}{|l|c|c|}
\hline \multirow{2}{*}{ Carcinogens } & \multicolumn{2}{c|}{ Single-plant town } \\
\cline { 2 - 3 } & ICR & PCR \\
\hline Nickel & $2,76 \mathrm{E}-06$ & 0,015 \\
\hline Lead & $2,7 \mathrm{E}-06$ & 0,015 \\
\hline Cadmium & $1,09 \mathrm{E}-05$ & 0,06 \\
\hline Chrome (6) & $7,6 \mathrm{E}-05$ & 0,4 \\
\hline benz(a)pyrene & $1,0 \mathrm{E}-03$ & 5,39 \\
\hline CR tot. & $1,09 \mathrm{E}-03$ & 5,9 \\
\hline
\end{tabular}

The data in the above table shows that the total individual carcinogenic risk to public health in single-plant towns reaches the level of 10-3 throughout the life and is considered high. The results show that in terms of non-carcinogenic effects development, single-plant towns with a total hazard index from air pollutants equal to 22.86 present the biggest risk to public health 
adjusted for the calculated hazard index. The total carcinogenic individual risk to children's health in single-plant towns reaches the level of $1.09 * 10-3$ throughout the life and is considered high. The obtained results show that single-plant towns are the most unfavorable in terms of development of non-carcinogenic and carcinogenic effects.

\section{References}

1.Boev V.M., Voljanik M.N. Antropogennoe zagrjaznenie okruzhajushhej sredy i sostojanie zdorov'ja naselenija Vostochnogo Orenburzh'ja [Anthropogenic environmental pollution and human health in the east of the Orenburg Region]. Ekaterinburg, 1995. 127 p.

2.Boev V.M., Kuksanov V.F., Bystryh V.V. Himicheskie kancerogeny sredy obitanija i zlokachestvennye novoobrazovanija [Environmental chemical carcinogens and malignant neoplasms]. Moscow.: Medicina, 2002. 344 p.

3. Boev V.M., Vereshhagin N.N., Skachkova M.A., Bystryh V.V., Skachkov M.V. Jekologija cheloveka na urbanizirovannyh i sel'skih territorijah [Human ecology in urban and rural areas]. Orenburg, 2003. 392 p.

4.Zajceva N.V., Pushkareva M.V., Gimervert D.A. Sostojanie zdorov'ja i analiz vzaimosvjazej v sisteme «sreda - zdorov'e naselenija» na jekologicheski neblagopoluchnyh territorijah [Human health and the analysis of relationships in the "environment - human health" system in environmentally unfavorable areas]. Jekologicheskaja bezopasnost' gorodov Urala: tezisy doklada regional'noj nauchno-tehnicheskoj konferencii. Perm', 1994, pp. 35-38.

5.Onishhenko G.G., Novikov S.M., Rahmanin Ju.A., Avaliani S.L., Bushtueva K.A. Osnovy ocenki riska dlja zdorov'ja naselenija pri vozdejstvii himicheskih veshhestv, zagrjaznjajushhih okruzhajushhuju sredu [The foundations of human health risk assessment of exposure to environmental pollutants]. Moscow, 2002. $407 \mathrm{p}$.

6.Prohorov B.B. Social'naja jekologija: uchebnik dlja stud. Vuzov [Social ecology: a textbook for students of higher educational institutions]. Moscow: Akademija, 2005. 416 p.

7.Prohorov B.B. Jekologija cheloveka. Ponjatijno-terminologicheskij slovar' [Human ecology. A glossary]. Moscow: Izd-vo MNJePU, 2000. 364 p.

8. Rukovodstva po ocenke riska R.2.1.10.1920-04 [Guidelines for risk assessment R.2.1.10.1920-04]. Available at: http://www.gosthelp.ru/text/R2110192004Rukovodstvopoo.html.

\section{A b o u t the a uthors:}

Boev Mikhail Viktorovich, $\mathrm{PhD}$ in Medicine (Orenburg, Russia) - Docent of the Department of General and Public Hygiene, the State Budgetary Educational Institution of Higher Professional Education "Orenburg State Academy of Medicine" of the RF Ministry of Public Health and Social Development (6 Sovietskaya St, Orenburg, 460000, email: boevm@inbox.ru, tel.: +7 (3532) 77-71-26, mobile: +7 903366 8119).

Neplokhov Andrei Alexandrovich, PhD in Medicine (Orenburg, Russia) - Head of the Risk Assessment Department, the Federal Budgetary Health Care Institution "The Orenburg Region Center for Hygiene and Epidemiology" (48 Kirova St, Orenburg, 460000, email: fguz2005@mail.ru, tel.: +7 (3532) 77-90-62).

Professor Boev Victor Mikhailovich, DSc in Medicine (Orenburg, Russia) - Rector of the State Budgetary Educational Institution of Higher Professional Education "Orenburg State Academy of Medicine" of the RF Ministry of Public Health and Social Development (6 Sovietskaya St, Orenburg, 460000, email: orgma@esoo.ru, tel.: +7 (3532) 77-61-03).

Tulina Larisa Mikhailovna, $\mathrm{PhD}$ in Medicine (Orenburg, Russia) - Head of the Social and Hygiene Monitoring Department, the Federal Budgetary Health Care Institution "The Orenburg Region Center for Hygiene and Epidemiology" (48 Kirova St, Orenburg, 460000, email: fguz2005@mail.ru, tel.:+7 (3532)77-28-77). 